\title{
Chromosome numbers of selected species of Elatine L. (Elatinaceae)
}

\author{
Anna Kalinka1,2*, Gábor Sramkó ${ }^{3,4}$, Orsolya Horváth ${ }^{3}$, Attila Molnár V. ${ }^{3}$, Agnieszka Popiela ${ }^{2,5}$ \\ 1 Department of Cell Biology, Faculty of Biology, University of Szczecin, Wąska 13, 71-415 Szzzecin, Poland \\ ${ }_{2}^{2}$ Molecular Biology and Biotechnology Center, Faculty of Biology, University of Szczecin, Wąska 13,71-415 Szczecin, Poland \\ ${ }^{3}$ Department of Botany, Unversity of Debrecen, Egyetem tér 1, Debrecen 4032, Hungary \\ ${ }^{4}$ MTA-ELTE-MTM Ecology Research Group, Pázmány Péter stny. 1/C., Budapest 1117, Hungary \\ ${ }^{5}$ Department of Botany and Nature Conservation, Faculty of Biology, University of Szczecin, Felczaka 3a, 71-412 Szczecin, Poland
}

\section{Abstract}

The paper reports chromosome numbers for 13 taxa of Elatine L., including all 11 species occurring in Europe, namely E. alsinastrum, E. ambigua, E. brachysperma, E. brochonii, E. californica, E. campylosperma, E. gussonei, E. hexandra, E. hungarica, E. hydropiper, E. macropoda, E. orthosperma, E. triandra originating from 17, field-collected populations. For seven of them (E. ambigua, E. californica, E. campylosperma, E. brachysperma, E. brochonii, E. hungarica, E. orthosperma) the chromosome numbers are reported for the first time. With these records, chromosome numbers for the whole section Elatinella Seub. became available. Although $2 n=36$ was reported to be the most common and the lowest chromosome number in the genus, our data show that out of thirteen species analyzed, six had 36 chromosomes but five species had 54 chromosomes, and the lowest number of chromosomes was 18. These data further corroborates that the basic chromosome number in Elatine is $x=9$.

Keywords: ephemeral taxa; polyploids; diploid; Europe; Asia; North America; Elatine; chromosome number

\section{Introduction}

Elatine L. is one of the two genera of the family Elatinaceae belonging to Malpighiales [1,2] and containing ca. 15-25 ephemeral, amphibious species occurring mainly in temperate regions of both hemispheres [3]. Most of the species are facultative autogamous. In recent years, they are of interest to European researchers because of their rarity throughout the range, relatively poorly known distribution and taxonomy, erratic temporal appearance that depends mainly on environmental factors, as well as ecology [4-14].

Chromosomes in Elatine L. are very small and thus difficult to count and analyze. So far only few taxa have been studied: E. hydropiper L. [15,16], E. triandra subsp. americana (Pursh) Á. Löve \& D. Löve [17], E. americana (Pursh) Arn. [18], E. macropoda Guss. [19], E. hexandra (Lapíerre) DC [20], E. gratioloides A. Cunn. [21], E. alsinastrum L. [22] and E. gussonei (Sommier) Brullo, Lanfr., Pavone \& Ronsisv. [23]. Some of these data, especially the oldest ones, are contradictory, as these are not supported with good quality pictures making the counting in many cases to be equivocal. Nevertheless, the previous records hint at a basic number of 9 [15,24,25], implying tetraploid, hexaploid, octoploid and even dodecaploid ploidy levels for the species [26].

\footnotetext{
*Corresponding author. Email: akali@op.pl
}

Handling Editor: Elżbieta Bednarska-Kozakiewicz
The aim of this study was to count the chromosome numbers for 13 Elatine species, originated from 17 populations. This was done to support our ongoing work to unravel phylogenetic relationship within the European members of the genus. For seven of the taxa studied, namely: E. ambigua Wight, E. californica A. Gray, E. campylosperma Seub., E. brachysperma A. Gray, E. brochonii Clav. , E. hungarica Moesz and E. orthosperma Dueb., the chromosome numbers have not been reported yet.

\section{Material and methods}

Plants studied were collected in field across Europe, in Asia and North America (Tab. 1). The field-collected plants were cultivated at both the Center for Molecular Biology at the University of Szczecin and/or Department of Botany at the University of Debrecen. Once the plants reached maturity and produced seeds, these were either sent to Szczecin (in case of plants cultivated in Debrecen), or processed locally. Seeds were sown in $12.5 \times 8.5 \mathrm{~cm}$ plastic boxes on sterilized soil, which was continuously wetted with distilled water. Plants were grown in climate controlled culture chamber with $12 \mathrm{~h}$ /day light and 30000 LUX light intensity, temperatures: under light $22 \pm 2^{\circ} \mathrm{C}$ and under darkness $18 \pm 2^{\circ} \mathrm{C}$. Roots were immersed in $0.05 \%$ colchicine solution (Sigma-Aldrich, St. Louis, USA) for 3 hours at $16^{\circ} \mathrm{C}$, then washed in ice-cold distilled water for 
10 min. Pretreated roots were fixed in Carnoy's solution (absolute ethanol : glacial acetic acid 3:1 v/v) for 24 hours at $4^{\circ} \mathrm{C}$. Roots were washed in distilled water, and the root tips were dissected under a stereoscopic microscope. Each root tip was macerated directly on a microscope slide in a mixture of $4 \%$ (w/v) pectinase (Fluka, Buchs, Switzerland), 6\% (w/v) hemicellulase (Sigma-Aldrich, St. Louis, USA) and 4\% (w/v) cellulase (Sigma-Aldrich, St. Louis, USA) in $0.01 \mathrm{M}$ citric acid - sodium citrate buffer $(\mathrm{pH} 4.8)$, for 4 hours at $37^{\circ} \mathrm{C}$ in a humidity chamber. Root tips were carefully washed with $45 \%$ acetic acid. Each preparation was covered with a cover glass, heated for $20 \mathrm{~min}$ at $47^{\circ} \mathrm{C}$, and then the root tips were gently squashed. The cover slip was removed after freezing over dry ice, and the slides were air-dried overnight. Slides were dehydrated in a graded ethanol series $(70 \%, 96 \%$, and 99.8\%) at room temperature, air-dried and stained with DAPI $(1 \mu \mathrm{g} / \mathrm{ml}$; Sigma-Aldrich, St. Louis, USA) for $15 \mathrm{~min}$. The slides were rinsed briefly in distilled water, air-dried and mounted in Vectashield ${ }^{\oplus}$ Hard Set mounting medium for fluorescence (Vector Laboratories, Burlingame, USA) and analyzed with the epifluorescence microscope Axio Imager Z2 (Carl Zeiss, Oberkochen, Germany). The resulting images were captured and analyzed using the GenASIs software (Applied Spectral Imaging). From each species/ population about 50 slides were prepared and analyzed. In order to confirm the results chromosomes were counted in 30 well-spread metaphase plates.

\section{Results}

Altogether, we have analyzed chromosome numbers in 17 populations representing 13 species of Elatine (Tab. 1). For seven of the taxa studied, namely: E. ambigua Wight, E. californica A. Gray, E. campylosperma Seub., E. brachysperma A. Gray, E. brochonii Clav., E. hungarica Moesz and E. orthosperma Dueb., the chromosome numbers have not been reported yet. Probably the most unexpected record is the finding that E. campylosperma has $2 n=18$ chromosomes (Fig. 1a), and hence - as the basic number for Elatine genus is $x=9$ - is a diploid species. Populations from both localities (Italy, Spain) had the same chromosome number, and neither in this study, nor in the literature a diploid species of this genus was ever reported before. All other species had chromosome number corresponding to the tetraploid level $(2 n=4 x=36)$ or higher (Tab. 1$)$. We found that $E$. alsinastrum (Fig. 1b), E. brochonii (Fig. 1c), E. californica (Fig. 1d), E. hungarica (Fig. 1e), E. hydropiper (Fig. 1f) and E. orthosperma (Fig. $1 \mathrm{~g}$ ) are tetraploids with $2 n=4 x$ $=36$ chromosomes. Also, the ploidy level of $2 n=6 x=54$ seems to be common among species of the genus Elatine; such hexaploids are: E. ambigua (Fig. 1h), E. brachysperma (Fig. 1i), E. gussonei (Fig. 1j), E. macropoda (Fig. 1k) and E. triandra (Fig. 11). For all of these species tested, there was no variation in chromosome number between populations from various localities. Unique number of chromosomes $2 n$

Tab. 1 Species included in the study; population origins, number of chromosomes found.

\begin{tabular}{|c|c|c|c|c|}
\hline Species & Locality & Lat. $\left({ }^{\circ} \mathbf{N}\right)$ & Long. $\left({ }^{\circ} \mathbf{E}\right)$ & $\begin{array}{l}\text { Number of } \\
\text { chromosomes }\end{array}$ \\
\hline Elatine alsinastrum $\mathrm{L}$. & Poland: Staw Noakowski & 50.82 & 23.02 & $2 n=36$ \\
\hline E. ambigua Wight & Nepal: Aadarsh Nagar Tou & 27.72 & 52.08 & $2 n=54$ \\
\hline E. brachysperma A. Gray & USA: Fallbrook & 33.46 & -117.37 & $2 n=54$ \\
\hline E. brochonii Clav. & Spain: San Silvestre de Guzmán & 37.40 & -7.36 & $2 n=36$ \\
\hline E. californica A. Gray & USA: Los Angeles & 33.82 & -118.34 & $2 n=36$ \\
\hline E. campylosperma Seub. & Italy: Sardegna: Gesturi & 39.73 & 9.03 & $2 n=18$ \\
\hline E. campylosperma Seub. & Spain: El Rocío & 37.12 & -6.49 & $2 n=18$ \\
\hline $\begin{array}{l}\text { E. gussonei (Sommier) Brullo, Lanfr., } \\
\text { Pavone \& Ronsisv. }\end{array}$ & Spain: Casar de Cáceres & 39.33 & -6.25 & $2 n=54$ \\
\hline $\begin{array}{l}\text { E. gussonei (Sommier) Brullo, Lanfr., } \\
\text { Pavone \& Ronsisv. }\end{array}$ & Italy: Lampedusa & 35.51 & 12.56 & $2 n=54$ \\
\hline $\begin{array}{l}\text { E. gussonei (Sommier) Brullo, Lanfr., } \\
\text { Pavone \& Ronsisv. }\end{array}$ & Italy: Sicily: Modica & 36.76 & 14.77 & $2 n=54$ \\
\hline E. hexandra DC. & Spain: San Silvestre de Guzmán & 37.40 & -7.36 & $2 n=108$ \\
\hline E. hexandra DC. & Poland: Poznań (Milicz) & 51.55 & 17.35 & $2 n=108$ \\
\hline E. hungarica Moesz & Hungary: Konyár & 47.31 & 21.67 & $2 n=36$ \\
\hline E. hydropiper L. & Hungary: Tiszagyenda & 47.36 & 20.52 & $2 n=36$ \\
\hline E. macropoda Guss. & Italy: Sardegna: Olmedo & 40.63 & 8.41 & $2 n=54$ \\
\hline E. orthosperma Dueb. & Finland: Oulu & 65.06 & 25.47 & $2 n=36$ \\
\hline E. triandra Schkuhr & Hungary: Karcag & 47.27 & 20.90 & $2 n=54$ \\
\hline
\end{tabular}




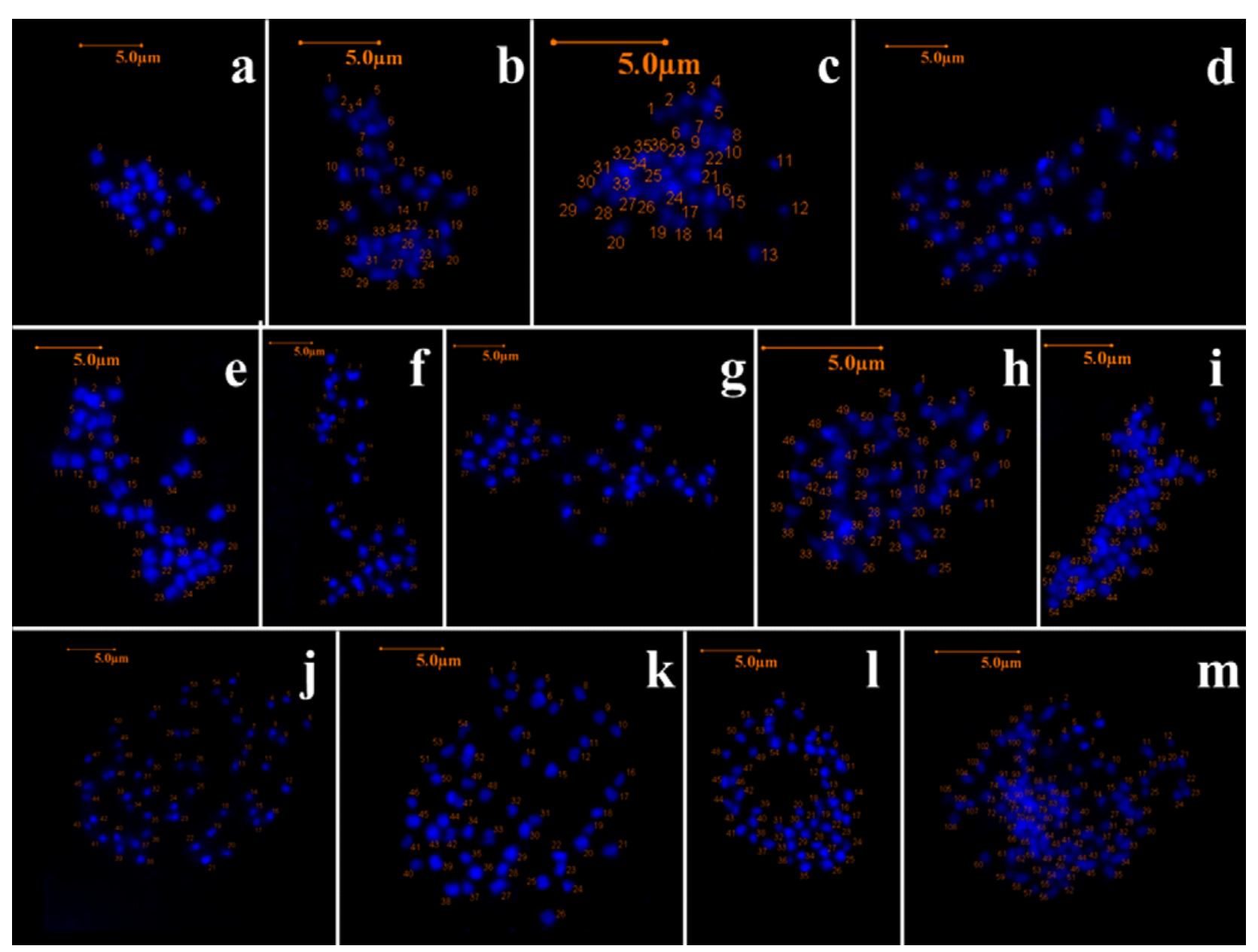

Fig. 1 Chromosomes of the analyzed Elatine species stained with DAPI (blue). a E. campylosperma $2 n=18$. b E. alsinastrum $2 n=36$. c E. brochonii $2 n=36$. d E. californica $2 n=36$. e E. hungarica $2 n=36 . \mathbf{f}$ E. hydropiper $2 n=36$. $\mathbf{g}$ E. orthosperma $2 n=36 . \mathbf{h}$ E. ambigua $2 n=54$. i E. brachysperma $2 n=54$. j E. gussonei $2 n=54 . \mathbf{k}$ E. macropoda $2 n=54.1$ E. triandra $2 n=54 . \mathbf{m}$ E. hexandra $2 n=108$.

$=12 x=108$ was found in E. hexandra (Fig. $1 \mathrm{~m})$, collected both from Poland and Spain (Tab. 1).

\section{Discussion}

According to literature data $[15,24,25]$ the basic number of chromosomes for the genus Elatine is $x=9$. This study strongly supports this view as all of the analyzed species had chromosome number dividable by 9 . Moreover, we report for the first time the existence of a diploid species, E. campylosperma, in the genus. No other diploid species in Elatine was reported so far. It was claimed [26] that different ploidy levels, such as tetraploids, octoploids and dodecaploids can exist within Elatine. In general, there are some dubious reports for chromosome numbers in the literature. One of the first chromosome number counts for an Elatine species was reported in 1974 [15], determining the chromosome number of $E$. hydropiper as equaling to $2 n=40$. However, subsequent studies showed that chromosome number in this taxon is $2 n=36$ [16]. Also, our study confirmed that the number of chromosomes of $E$. hydropiper counted in two populations is $2 n=36$. We also confirmed the same chromosome number $(2 n=36)$ for $E$. alsinastrum, in line of what was previously reported [22]. Actually, it was suggested that $2 n=36$ is the most common number and the lowest number of chromosomes in species of Elatine genus, as it was also found in the recently described species $E$. gratioloides [21], and the species with the widest distribution range in the genus, E. triandra [17]. In this study we showed that $E$. triandra can also have $2 n=54$ chromosomes, thus the tetraploid and hexaploid level can coexist in the genus. Examples of plant species with different ploidy-levels (i.e., coexistence of different cytotypes) is numerous [27-32], especially when they are autopolyploids.

Similarly doubtful is the record of Contandriopoulos et al. [19], who reported $2 n=40$ chromosomes in E. macropoda. Although this record much deviates from our counting, as we found $2 n=54$ in this species (Tab. 1), we cannot exclude that the material analyzed by the above authors was in fact $2 n=36$. Another example of coexistence of different ploidy-level cytotypes is E. hexandra, for which two different chromosome numbers are reported, $2 n=72,108$ [20]. In this paper we found that our Spanish and Polish material of 
E. hexandra had $2 n=12 x=108$, but we cannot rule out that some populations of the species have different chromosome number. This view is further corroborated by the finding of Probatova and Sokolovskaya [18], who reported that other species, i.e., E. americana can also have $2 n=(70-) 72$. The differences in the chromosome number counts in Elatine clearly demonstrate how difficult is to determine the number of such small chromosomes, and that there is a need to perform a number of tests and optimization to obtain accurate results. It should be noted that when the chromosomes are small in size and there are many of them in one cell, it is extremely difficult to obtain well-spread metaphase plates as, depending on the procedure of preparation, chromosomes may overlap or the metaphase plate may be incomplete. Both cases can lead to counting errors with a tendency to underreporting the number of chromosomes.

In our previous study we reported that E. gussonei collected from the Maltese Archipelago has the number of $2 n$ $=8 x=54$ chromosomes [23]. Here, we have confirmed this result by adding two more populations from geographically distant locations. It is important to analyze the chromosome number from different population as some chromosome rearrangements may lead to the change of the chromosome number in genetically isolated populations. Unfortunately, we were not able to distinguish the types of chromosomes because of their minute size. Karyotyping could shed some light on the possibilities of chromosome rearrangements, which can be the reason for varying chromosome number. Consequently, we cannot totally exclude the existence of some populations of the same species with different chromosome number (e.g., $2 n=40$ in case of a $2 n=36$ species), but there is a slightly higher likelihood of incorrectly counting more chromosomes due to their small size.

Another aspect of chromosome number changes is the phenomenon of polyploidization itself. This aspect may explain different number counts in different reports. Most of the Elatine species are polyploids and it is a well-known fact that meiosis in newly formed polyploids is unstable $[33,34]$. For example, several studies found that $30-40 \%$ of the progeny of autotetraploid maize is aneuploid [35]. If aneuploids became isolated, they might give rise to a population with different chromosome number. Polyploid meiosis frequently produces aneuploid gametes, although their frequency varies between species or ploidy level. There is a relationship between polyploidy and aneuploidy: eupolyploids produce frequently aneuploids, which in turn can produce euploids [33].

It is believed, that polyploidization is a major driving force of plant evolution [36,37]. Obtained chromosome number data clearly indicate that polyploidization was one of the most important phenomena accompanying the evolution of the genus Elatine. Further studies should bring the answer to the question if E. campylosperma is one of the ancestors of polyploids. Another question is whether these species are auto- or allopolyploids, which originated through hybridization event between different species, accompanied or followed by genome duplication. Also interesting is to correlate ploidy level in Elatine to geographic latitude the species most commonly inhabit. As it is demonstrated in Europe and North America [38], polyploids are more frequent at high latitudes. If we examine our list of chromosome numbers, we found that the European species found exclusively in the temperate climate zone (E. hungarica, E. hydropiper and $E$. orthosperma) have $2 n=4 x=36$. Two of three Mediterranean species (E. gussonei, E. macropoda) have $2 n=6 x=54$. This is an apparent contradiction to the above rule, and requires the reconstruction of phylogenetic relationships for a better understanding. Whatever the pattern behind this finding, the large chromosome number differences between different Elatine species suggests that the genome of Elatine is very tolerant to redundancy of genetic information, and its evolution was accompanied by multiple polyploidization events.

\section{Acknowledgments}

This work was supported by the National Science Centre, Poland under grant No. N N303 470638 (AP). The work of the Hungarian co-authors (GS, OH, AMV) was supported by the grants of the Hungarian Scientific Research Fund (OTKA PD109686, OTKA K108992) and TÁMOP-4.2.2.B-15/1/ KONV-2015-0001 grant. The work of GS was supported by the János Bolyai Scholarship of the Hungarian Academy of Sciences.

We wish to thank for field collection of plant/seeds sample to Arkadiusz Nowak and Sylwia Nowak (Opole, Poland), Balázs Lukács (Debrecen, Hungary), Attila Mesterházy (Sárvár, Hungary), Viktor Löki (Debrecen, Hungary), as well as to Andrzej Łysko (Szczecin, Poland) and Wiaczesław Michalczuk (Zamość, Poland) for the assistance during field work (AP). The laboratory cultivation of plants is gratefully thanked to Teresa Dzieńkowska (Poland).

The authors are very grateful to the reviewers for detailed valuable comments on the manuscript. Their suggestions were helpful in improving the manuscript. The authors would like to kindly acknowledge them.

\section{Authors' contributions}

The following declarations about authors' contributions to the research have been made: conducting experiments, writing the manuscript: AK; field sampling, manuscript preparation: GS; field sampling, cultivating plants: $\mathrm{OH}$; research idea and coordination in Debrecen, field sampling, manuscript preparation: AM; research idea and coordination in Szczecin, field research, manuscript preparation: AP.

\section{Competing interests}

No competing interests have been declared.

\section{References}

1. Davis CC, Chase MW. Elatinaceae are sister to Malpighiaceae; Peridiscaceae belong to Saxifragales. Am J Bot. 2004;91:262-273. http:// dx.doi.org/10.3732/ajb.91.2.262

2. Tucker GC. The genera of Elatinaceae in the southeastern United States. J Arnold Arbor. 1986;67:471-483.

3. Heywood V, Brummitt R, Culham A, Seberg O, editors. Flowering plant families of the world. Kew: Royal Botanic Gardens; 2007.

4. Misfud S. A comparative study between Elatine gussonei (from Malta) and Elatine macropoda (from Majorka) [Internet]. 2006 [cited 2015 Dec 4]; Available from: http://www.aquatic-gardeners.org/Articles/ elatine/Comparitive_study.pdf

5. Uotila P. Lectotypifications in Elatine (Elatinaceae) and some taxonomic remarks. Ann Bot Fenn. 2009;46(2):90-94. http://dx.doi. org/10.5735/085.046.0202

6. Popiela A, Łysko A. The distribution of Elatine macropoda Guss. (Elatinaceae). Acta Soc Bot Pol. 2010;79:81-86. http://dx.doi.org/10.5586/ asbp. 2010.011

7. Popiela A, Łysko A, Wieczorek A, Nalepka D. The distribution of 
Elatine hexandra (Lapierre) DC. (Elatinaceae). Acta Soc Bot Pol. 2011;80:27-32. http://dx.doi.org/10.5586/asbp.2011.004

8. Popiela A, Łysko A, Wieczorek A, Molnár VA. The distribution of Elatine hydropiper L. (Elatinaceae). Acta Soc Bot Pol. 2012;81:137-143. http://dx.doi.org/10.5586/asbp.2012.009

9. Takács A, Schmotzer A, Jakab G, Deli T, Mesterházy A, Király G, et al. Key environmental variables affecting the distribution of Elatine hungarica in the Pannonian Basin. Preslia. 2013;85(2):193-207.

10. Molnár VA, Horváth O, Tökölyi J, Somlyay L. Typification and seed morphology of Elatine hungarica Moesz (Elatinaceae). Biologia. 2013;68(2):210-214. http://dx.doi.org/10.2478/s11756-013-0007-7

11. Molnar VA, Popiela A, Lukacs BA. Elatine gussonei (Sommier) Brullo et al. (Elatinaceae) in Sicily. Plant Biosyst. 2013;148(1):27-30. http:// dx.doi.org/10.1080/11263504.2013.788099

12. Šumberová K, Hrivnák R. Formalised classification of the annual herb vegetation of wetlands (Isoëto-Nano-Juncetea class) in the Czech Republic and Slovakia (Central Europe). Phytocoenologia. 2013;43(12):13-40. http://dx.doi.org/10.1127/0340-269X/2013/0043-0529

13. Molnár VA, Tóth JP, Sramkó G, Horváth O, Popiela A, Mesterházy A, et al. Flood induced phenotypic plasticity in amphibious genus Elatine (Elatinaceae). PeerJ. 2015;3:e1473. http://dx.doi.org/10.7717/ peerj. 1473

14. Popiela A, Łysko A, Molnár VA, Kącki Z, Lukács BA. Distribution, morphology and habitats of Elatine triandra (Elatinaceae) in Europe, with particular reference to the central part of the continent. Acta Bot Gallica. 2015;162(4):325-337 http://dx.doi.org/10.1080/12538 078.2015 .1088470

15. Löve Á, Löve D. Cytotaxonomical atlas of the Slovenian flora. Lehre: J Cramer; 1974.

16. Krahulcová A. Selected chromosome counts of the Czechoslovak flora II. Folia Geobot Phytotax. 1990;25:381-388.

17. Löve Á, Löve D. IOPB chromosome number reports 75 . Taxon. 1982;31:344-360.

18. Probatova NS, Sokolovskaya AP. Chromosome numbers of the vascular plants from the far east of the USSR. Bot Zhurn SSSR. 1986;71:1572-1575.

19. Contandriopoulos J, Noguet $\mathrm{D}$, Zevaco-Schmitz C. Contribution à l'étude de quelques espèces interessantes de Corse: cytotaxonomie et comportement écologique. Biol Ecol Méditerr. 1987;10:259-271.

20. Pogan E, Jankun A, Sawicka Z. Further studies in chromosome numbers of Polish angiosperms, part 22. Acta Biol Cracov Ser Bot. 1990;31:1-17.

21. de Lange PJ, Murray BG, Datson PM. Contributions to a chromosome atlas of the New Zealand flora, 38. Counts for 50 families. NZ J Bot. 2004;42:873-904. http://dx.doi.org/10.1080/0028825X.2004.9512936

22. Schotsman HD. Note sur Elatine alsinastrum L., II- le nombre chromosomique. Bull Centr Etudes Rech Sci. 1969;7:865-868.

23. Kalinka A, Mifsud S, Popiela A, Achrem M. Chromosome number of Elatine gussonei (Sommier) Brullo (Elatinaceae) and its distribution on the Maltese islands. Acta Bot Croat. 2014;73(1):267-273. http:// dx.doi.org/10.2478/botcro-2013-0022

24. Goldblatt P. Index to plant chromosome numbers 1975-1978. Saint Louis, MO: Missouri Botanical Garden; 1981. (Monographs in Systematic Botany from the Missouri Botanical Garden; vol 5).

25. Goldblatt P. Index to plant chromosome numbers 1982-1983. Saint Louis, MO: Missouri Botanical Garden; 1985. (Monographs in Systematic Botany from the Missouri Botanical Garden; vol 13).

26. Uotila P. Elatine hydropiper L. aggr. in Northern Europe. Memo Soc Fauna Flora Fenn. 1978;50:113-123.

27. Clement WM Jr. Chromosome numbers and taxonomic relationships in Medicago. Crop Sci. 1962;2:25-28. http://dx.doi.org/10.2135/crop sci1962.0011183X000200010008x

28. Bingham ET. Registration of alfalfa germplasm from cultivated $\times$ wild hybrids. Crop Sci. 1975;5:889. http://dx.doi.org/10.2135/cropsci1975 .0011183 X001500060058x

29. Barnes D, Bingham ET, Murphy RP, Hunt OJ, Beard DF, Skrdla WH, et al. Alfalfa germplasm in the United States: genetic vulnerability, use, improvement, and maintenance. Washington, DC: U.S. Dept. of Agriculture, Agricultural Research Service; 1977. (Technical Bulletin; vol 1571).

30. Lesins K, I. Lesins I. Genus Medicago (Leguminosae). A taxonomic study. The Hague: Junk; 1979. http://dx.doi. org/10.1007/978-94-009-9634-2

31. Emshwiller E. Ploidy levels among species in the "Oxalis tuberosa alliance" as inferred by flow cytometry. Ann Bot. 2002;89(6):741-753. http://dx.doi.org/10.1093/aob/mcf135

32. Eidesen PB, Eike Müller E, Lettner C, Alsos IG, Bender M, Kristiansen $\mathrm{M}$, et al. Tetraploids do not form cushions: association of ploidy level, growth form and ecology in the High Arctic Saxifraga oppositifolia L. s. lat. (Saxifragaceae) in Svalbard. Polar Res. 2013;32:20071. http:// dx.doi.org/10.3402/polar.v32i0.20071

33. Comai L. The advantages and disadvantages of being polyploidy. Nat Rev Genet. 2005;6:836-846. http://dx.doi.org/10.1038/nrg1711

34. Lim KY, Soltis DE, Soltis PS, Tate J, Matyasek R, Srubarova H, et al. Rapid chromosome evolution in recently formed polyploids in Tragopogon (Asteraceae). PLoS ONE. 2008;3(10):e3353. http://dx.doi. org/10.1371/journal.pone.0003353

35. Doyle GG. Aneuploidy and inbreeding depression in random mating and self-fertilizing autotetraploid populations. Theor Appl Genet. 1986;72:799-806. http://dx.doi.org/10.1007/BF00266548

36. Madlung A. Polyploidy and its effect on evolutionary success: old questions revisited with new tools. Heredity. 2013;110:99-104. http:// dx.doi.org/10.1038/hdy.2012.79

37. Soltis DE, Visger CJ, Soltis PS. The polyploidy revolution then... and now: Stebbins revisited. Am J Bot. 2014;101(7):1057-1078. http:// dx.doi.org/10.3732/ajb.1400178

38. Levin DA. The role of chromosomal change in plant evolution. Oxford: Oxford University Press; 2002. 